\title{
Lógica de organização territorial guarani: concepções do modo de ser
}

SELECCIÓN VIII SEMINARIO INTERNACIONAL DE INVESTIGACIÓN EN URBANISMO

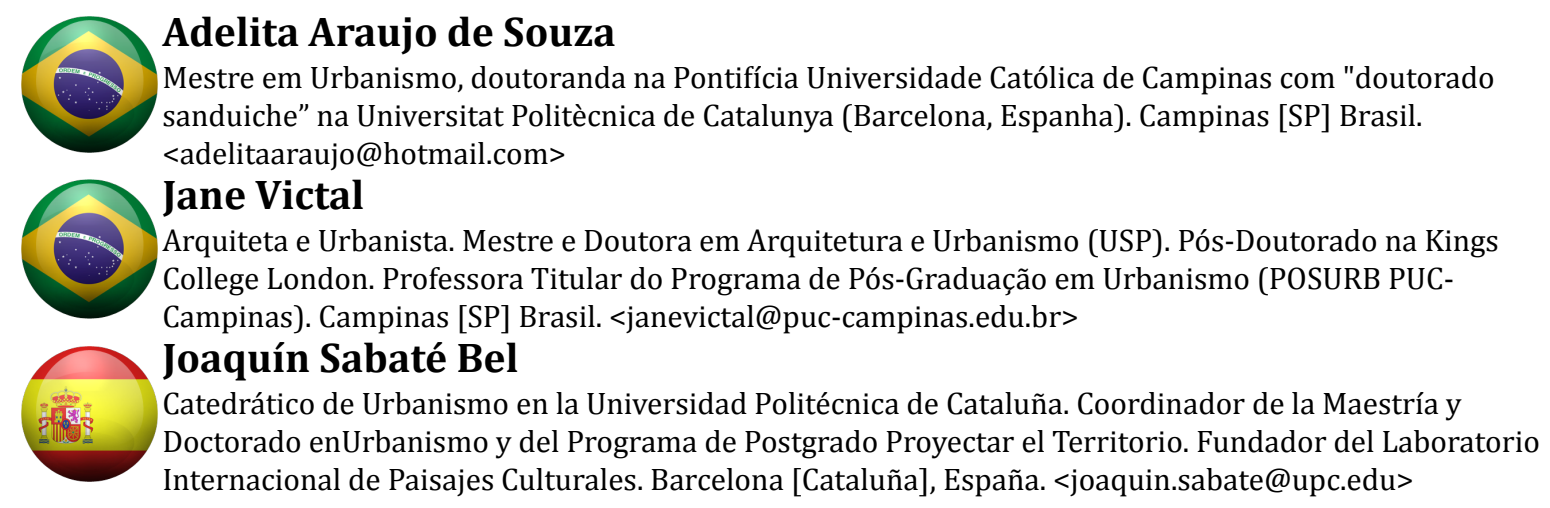

\section{Resumo}

O objetivo da pesquisa é demonstrar que a cultura guarani possui uma lógica de organização territorial estreitamente relacionada com as características do território. Parte-se do conceito de Paisagem Cultural para reconhecer essa lógica, e se valora como ao longo da história se produzem sucessivas intenções de aculturação, que fundamentalmente se baseiam na pretensão de impor modelos urbanos como meio civilizatório. Apesar de todo o processo de aculturação, se pretende demonstrar que os guaranis ainda preservam traços de sua antiga organização, servindo como suporte para manter suas tradições e seu modo de vida. Neste artigo, apresentamos os padrões culturais dos seus assentamentos, baseando-se principalmente nas narrativas de jesuítas, para depois comparar com a legislação portuguesa de 1755 , que inicia um sistema de urbanização utilizando a população indígena como meio de organização e defesa do território.

\section{Palavras-chave}

Paisagem cultural.Organização territorial. Guarani.

\section{The logical of territorial organization of the guaranies: conceptions of the way of beeing}

\begin{abstract}
The main research objective is to demonstrate that the Guarani's culture has an organization pattern closely linked to the territorial features. We use the concept of Cultural Landscape to recognize this logic, and we try to show how successive attempts of acculturation happen along the time, based on the intention to impose a different urban model as a means of civilization. However we want to show how the Guaranis still try to defend traces of their old organization, serving as a basis to maintain their traditions and their way of life. In this article we present the cultural patterns of their settlements, based mainly in the narratives of the Jesuits, comparing them with the Portuguese legislation of 1755 , which starts a settlement system and requires the formation of cities as the unique alternative to the territorial native organization.
\end{abstract}

\section{Keywords}

Cultural landscape. Territorial organization. Guarani. 


\section{Introdução}

Para cá se retirou também o restante de uma horda dispersa da outrora poderosa tribo Guarani. Glorificados no leste e feitos heróis de romances, são eles aqui no oeste desprezados e maltratados como gado miserável. Há três anos ecoa na mata do sertão o apito da locomotiva, sinalizando que também aqui acabou o tempo para os criminosos e para os índios, e, silenciosos e sem queixar-se, como é de sua índole, desaparecem do Estado de São Paulo os últimos indígenas, sem que ninguém tenha por eles outro interesse, senão o de explorá-los. Trata-se, aliás, de índios "mansos", e prevalece, nesse caso, o julgamento habitual, tradicional preguiçosos, ladrões e bêbados — quando não se levantam acusações ainda piores, urdidas pela fantasia de visitantes superficiais. Um julgamento desse tipo é, aliás, muito mais cômodo do que o estudo trabalhoso da concepção de mundo dos índios e do caráter fechado destes povos com todas as suas excelências e deficiências (Nimuendajú, 1910).

0 testemunho do jovem antropólogo, que nasceu Alemão de nome Kurt Unckel, e morreu brasileiro de nome Nimuendajú ${ }^{1}$, mostra o desprezo e a marginalização histórica que a cultura guarani está submetida, situação que se soma a ineficácia da política indigenista do Brasil, que historicamente se mostrou incapaz de atuar através das concepções do mundo guarani, produzindo medidas que mais se aproximam da privação dos direitos à terra do que em defesa dos direitos culturais e sociais da população. No texto de Nimuendajú, escrito no ano de 1910, o antropólogo observa o avanço das infraestruturas no território, "há três anos ecoa na mata do sertão o apito da locomotiva" e alerta para o desaparecimento da cultura guarani afirmando: "sinalizando que também acabou o tempo para os criminosos e para os índios", palavras que de fato se concretizam, ao menos para os índios, já que no decorrer do último século os processos de desenvolvimento territorial e a intensa urbanização, atuaram como o principal motivo da desestruturação do território guarani, desconsiderados enquanto cultura e desrespeitados enquanto direitos.

Na atualidade podemos perceber diversas ações que ainda fomentam uma dura campanha de negação a cultura guarani, população que não é aceita na sociedade tradicional e está submetida a uma política de reserva indígena como única alternativa de direito à terra. 0 prefeito da cidade de Guaíra [PR], fronteira com o Paraguai, fala sobre a possibilidade da Funai regularizar 13 aldeias guaranis com 2.500 pessoas: "Nasci aqui e vou completar 50 anos vivendo aqui. Não tenho lembrança de vê-los. Se houve indígenas nos últimos cem anos, não os considerávamos como indígenas. Para nós, eram paraguaios que viviam em Guaíra" (Breda, 2014, p.15). E finaliza, “...0 povo quer resolver o problema dos índios" (Breda, 2014, p.17). Citando supostas tentativas de construir casas populares para 88 famílias guaranis no perímetro urbano da cidade.

O propósito desta pesquisa é demonstrar que a cultura guarani possui uma lógica de organização territorial que pode ser compreendida pelo conceito de Paisagem Cultural, conceito cunhado pelo geógrafo Carl Sauer no ano de 1925. Interessa compreender a forma de ocupação desta cultura, que historicamente abrangia toda a bacia do Prata e atualmente encontra-se fracionada e restrita a pequenas áreas na fronteira do Brasil, Paraguai e Argentina.

Como hipótese principal pretende-se argumentar que a organização do grupo responde a uma lógica relacionada com as características e recursos do território, com uma estrutura social e um conjunto de tradições que dão sentido ao seu modo de vida e a maneira como satisfazem suas necessidades humanas.

Posteriormente busca-se demonstrar que os sucessivos processos históricos de aculturação e expulsão, foram conduzidos pela imposição de organizações territoriais e urbanas que pretendiam explorá-los e substituir seus padrões culturais e sua organização territorial original. É importante destacar, que o desinteresse em reconhecer os padrões culturais, culminou em poucos casos de adaptação e interação cultural, com ciclos alternados de extermínio das populações e retomadas sucessivas ao antigo padrão de organização territorial guarani.

\footnotetext{
${ }^{1}$ Em 1910 Kurt Unckel passa pelo ritual Nimongaraí onde recebe o seu nome Guarani, "Nimuendajú”, (aquele que encontrou seu lugar entre nós) nome que passa a adotar e utilizar em suas publicações na Alemanha. Pelas tradições guarani o nome é parte integrante do ser e no momento do ritual Nimongaraí o líder espiritual revela o nome dos recém-nascidos.
} 
A metodologia está baseada em três tipos de análises, buscando compreender e valorar a conformação territorial da cultura guarani. Primeiramente, através de fontes antropológicas e geográficas, busca-se analisar a relação entre os elementos naturais e as práticas culturais que dão sentido a implantação de seus assentamentos, entendendo como os conhecimentos, as técnicas e o modo de vida estão relacionados com a paisagem e permitindo o desenvolvimento dessa cultura.

Em segundo lugar utilizamos a historiografia e a análise comparada de documentos, demonstrando como os diversos instrumentos de intervenção - fundamentalmente as legislações indigenistas produzidas desde o período colonial - utilizam o conceito de cidade para conduzir processos de aculturação e dominação guarani, modificando sua organização territorial, mas principalmente sua estrutura social, gerando mudanças que se incorporam aos padrões culturais e podem ser observadas na atual forma de habitar e constituir os lugares.

Como terceira analise a morfológica de alguns assentamentos guaranis do Brasil, localizados na proximidade da fronteira entre Paraguai e Argentina, para mostrar que esses grupos ainda buscam reproduzir e manter uma lógica de organização territorial, que, entretanto, se encontra ameaçada pelos modelos vigentes de produção do espaço, sinalizando para um processo eminente de extinção cultural e populacional.

A justificativa deste estudo, em reconhecer a lógica de ocupação territorial guarani, é demonstrar a valorização dessa cultura, o respeito por sua organização e sua relação territorial, que se mostra como um suporte de suas tradições e do "modo de ser guarani"2.

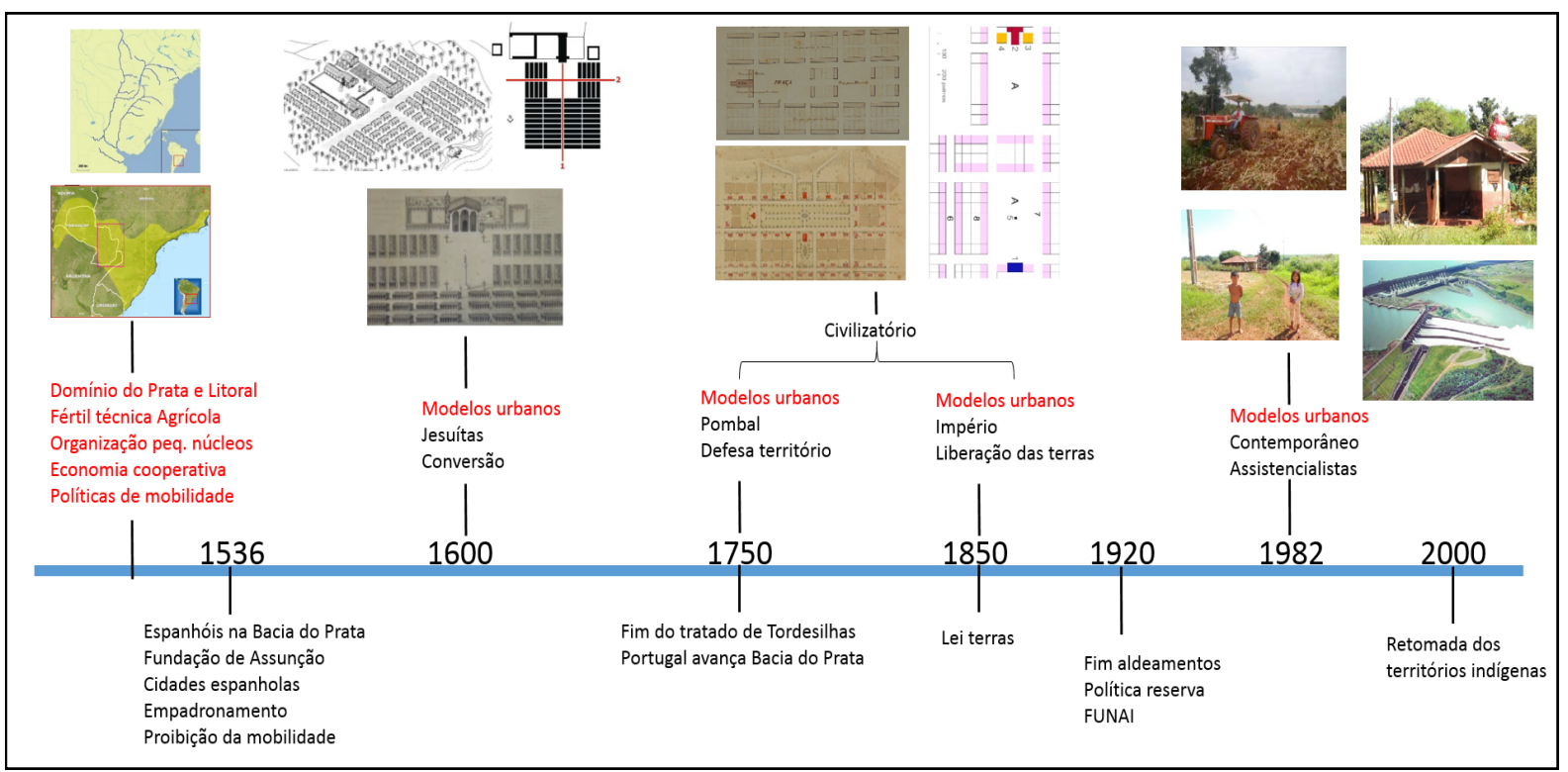

Figura 1. Cronograma temporal da Tese. Fonte: Elaboração própria.

É importante destacar que a cultura guarani sofre com um longo processo de aculturação, promovido desde a chegada dos primeiros europeus na América. Neste contexto podemos citar alguns momentos que causaram grande impacto cultural, começando pelos "encomendeiros" espanhóis, as Reduções Jesuíticas, seguindo com as legislações de aldeamentos de 1755 e 1845, ou mais recentemente com os processos de expulsão para a formação de cidades, agricultura

\footnotetext{
${ }^{2}$ A grafia da palavra tekoha provêm de "teko'a", sendo que "teko" significa "modo de ser", o que equivale a nossa palavra "cultura". O "teko", ou "modo de ser" é interpretado pelos antropólogos e historiadores como a repetição das tradições de seus antepassados, pouco se fala sobre o sentido da palavra em relação a organização territorial e a constituição do lugar. Existe uma forte corrente, de que os guaranis só constituíram delimitação de território após a chegada dos europeus. Sua localização e organização atual é entendida como uma repetição de vínculos ancestrais, vínculo com cemitérios indígenas por exemplo, e não como uma organização territorial consciente e que produz o modo de ser. Entretanto os guaranis possuem uma relação muito estreita com o território, não compreendem a propriedade privada porque dizem que "não é o Guarani que possui o território, é o território que possui os Guaranis". Utilizam expressões como "Sem Tekohá não há teko", e "tekoha pequeno teko pequeno".
} 
mecanizada, construção de usinas hidrelétricas, como também as políticas de reservas indígenas. A partir da interpretação de documentos históricos, este artigo se propõe a abordar os aspectos desta organização guarani e uma pequena fração deste processo histórico de aculturação, concentrando-se em alguns documentos jesuíticos que falam sobre a cultura guarani e na legislação pombalina de 1755 , que introduziu pela primeira vez no Brasil a política de aldeamentos indígenas, observada neste artigo como uma tentativa de imposição do conceito de cidade e civilidade, contrapondo-se completamente a forma originária de habitar e se relacionar com o território.

\section{A Paisagem Cultural de Carl Sauer}

Esta pesquisa está baseada nas reflexões e na teoria formulada pelo geógrafo e professor Carl Sauer, que propaga na década de vinte, na Universidade de Berkeley, o termo e o uso do conceito de Paisagem Cultural.

Revisando a ideia de landschaft, Sauer aprofunda o que denomina de geografia cultural. 0 geógrafo teoriza sobre a paisagem estabelecendo que sua análise não pode ser realizada simplesmente pela soma de elementos físicos, sua natureza deve ser pensada como uma área composta por uma associação de formas distintas, tanto físicas quanto culturais. Que não se traduz apenas como um cenário, comtemplado por um observador, tão pouco como uma pintura que possui uma perspectiva limitada. A paisagem cultural deve ser compreendida e analisada como uma unidade orgânica, "compreendendo a vida e a terra nos termos uma da outra" (Bluntschli, apud Sauer, 1925, p. 299. Tradução nossa).

Dentre as qualidades físicas que uma paisagem cultural pode conter, é necessário observar as características que representam um valor ao habitat construído, que é a base determinante do seu conteúdo. As características gerais da paisagem cultural envolvem um sentido de valor e o uso desses recursos para os seres humanos. "Nós estamos interessados naquela parte da cena que possui relação com o homem, porque nós somos parte dela" (Sauer, 1925, p. 302. Tradução nossa) "Estamos interessados em culturas que crescem com vigor original a partir do colo de uma paisagem natural materna, ao qual cada uma está vinculada em todo o curso de sua existência" (Sauer, 1925, p.303. Tradução nossa).

Pensando a Paisagem Cultural Guarani, podemos observar características do território que são condicionantes de sua cultura, a exemplo disso temos os grandes rios, que proporcionam a comunicação entre os grupos; o clima e a vegetação, que permitem o tipo de técnica agrícola; o relevo e o solo, que condicionam a localização e o tipo de implantação dos assentamentos.

Sauer também explica que a presença de alguns recursos pode não ser determinante para o desenvolvimento cultural, por que nem todos os recursos são utilizados e escolhidos pelo homem, e não devem ser descritos e analisados como parte da paisagem cultural.

Segundo Sauer, sempre será possível observar uma diversidade de paisagens culturais sobre a terra, que derivam de uma sucessão de diferentes culturas, pois cada cultura está ligada as formas naturais de sua área, sendo o homem o agente que distingue as modificações e transforma as paisagens em cenários únicos na terra.

Sauer explica que a "paisagem cultural é uma área geográfica em sentido final". (Sauer, 1925, p.309. Tradução nossa). A paisagem cultural tem uma constituição histórica, é formada de um grupo cultural que ao longo do tempo construiu suas formas e o seu modo de vida, relacionando-se com a paisagem natural. As formas da paisagem cultural "são todas as obras do homem que podem caracterizar uma paisagem. A cultura é o agente, a área natural é o meio e a paisagem cultural o resultado" (Sauer, 1925, p.309. Tradução nossa).

Antes da chegada do homem Europeu o grupo Guarani se mostra como uma grande civilização em todo o território da bacia do Prata e litoral do Brasil. Seus assentamentos, casas, plantações, cerâmicas, artes em plumagem, pintura e cestarias se desenvolveram ao longo dos séculos e são resultado da relação do homem com o território. 
No contexto dessas modificações humanas sobre a paisagem natural encontramos o fator tempo, visto que o desenvolvimento de qualquer cultura se faz ao longo de um período histórico, possuindo fases de desenvolvimento, que encontra o seu ápice e amadurecimento em um dado momento da história, e é o que entendemos por civilização.

Em cada fase desse desenvolvimento cultural a paisagem se transforma, recebe novas formas, que são marcadas em uma linha do tempo, transformações que paulatinamente passam a alterar as formas naturais, criando formas culturais, formas da produção humana. Ao longo da formação dessa linha do tempo, a paisagem adquire uma característica mutante, torna-se sujeita a alterações produzidas pelo homem, acumulando etapas que "alcançam, provavelmente, o fim de um ciclo de desenvolvimento" (Sauer, 1925, p. 309).

Sauer explica que não se trata de pensar a paisagem cultural como um objeto estático, ela está em continua movimentação pelas alterações humanas, o fim de um ciclo caracteriza o início de um novo ciclo, com a introdução de um novo grupo na área, ou seja, um grupo cultural "proveniente de fora", momento em que "ocorre o rejuvenescimento dos cenários da paisagem cultural" (Sauer, 1925, p.310. Tradução nossa), desenvolvendo-se as técnicas e os modos de vida do homem. Ou ainda, em outra situação, é o momento em que ocorre a sobreposição de paisagens culturais, o novo grupo cultural cria ou impõe novas maneiras de utilizar os recursos naturais disponíveis, introduzindo novas formas que se sobrepõe aos remanescentes da paisagem cultural anterior.

A chegada do homem europeu é o momento em que se caracteriza o fim de um ciclo de desenvolvimento da cultura guarani, inicia-se a modificação e o declínio dessa cultura. 0 homem europeu, "proveniente de fora", impõe a sua forma de se organizar, viver e se relacionar, em um processo de aculturação que através dos séculos se sobrepõe a paisagem cultural guarani.

\section{Organização territorial guarani: o que o território tem a nos dizer}

\section{O Europeu não sabia mais do que o Guarani, sabia menos. o Guarani sabia tudo o que precisava saber, o Europeu não.}

Segundo o dicionário Aurélio pode designar-se como um povo o conjunto de indivíduos que falam a mesma língua e possuem costumes, tradições, hábitos, afinidades, interesses e uma história em comum. Tratamos o grupo Guarani como um povo, uma civilização que no decorrer da história interagiu com as condições do território e se diferenciou dos outros grupos humanos, constituindo uma cultura estável e que ainda hoje mostra resistência aos processos de aculturação.

Os guaranis ocupavam historicamente, antes da chegada do homem europeu, uma grande área no território, que se estendia por toda a bacia platina e parte do litoral brasileiro. Na atualidade estão concentrados na fronteira entre o Brasil, Paraguai e Argentina, (em destaque na Figura 2) e são cerca de 100.000 pessoas distribuídas em aproximadamente 500 aldeias e/ou comunidades nos três países. No Brasil existem aproximadamente 30 mil pessoas e 3 mil no Estado do Paraná.

O grupo se divide em quatro etnias diferentes Mbya, Kaiowá, Nandeva e Ache-Guayakí, todos com grande semelhança nos aspectos fundamentais da cultura e da organização social, política e territorial, porém com algumas diferenças no modo de falar Guarani, praticar a religião e aplicar as técnicas produtivas, ligadas fundamentalmente com as condições locais do território.

Quando os espanhóis e portugueses chegaram na América, os Guaranis já falavam um mesmo idioma e haviam desenvolvido um modo de ser que mantinha viva as suas memórias e as suas tradições. Possuíam assentamentos fixos, não eram nômades e não viviam apenas da pesca e da coleta de alimentos, eram fundamentalmente agricultores, e praticavam uma agricultura muito produtiva, deixando os espanhóis maravilhados com a "divina abundancia" de alimentos, que incluía milho, mandioca, batatas, feijão andu, amendoim, cará, abóboras e repolhos, bananas e ananás - abacaxi, de diferentes espécies, assim como outros cultivos. A agricultura dos guaranis gerava muitos excedentes que motivavam grandes festas, distribuindo produtos e renovando as relações de amizade e trabalho, promovendo uma grande economia pela reciprocidade. (Azevedo, Brand, Heck, Pereira, \& Melià, 2008). 


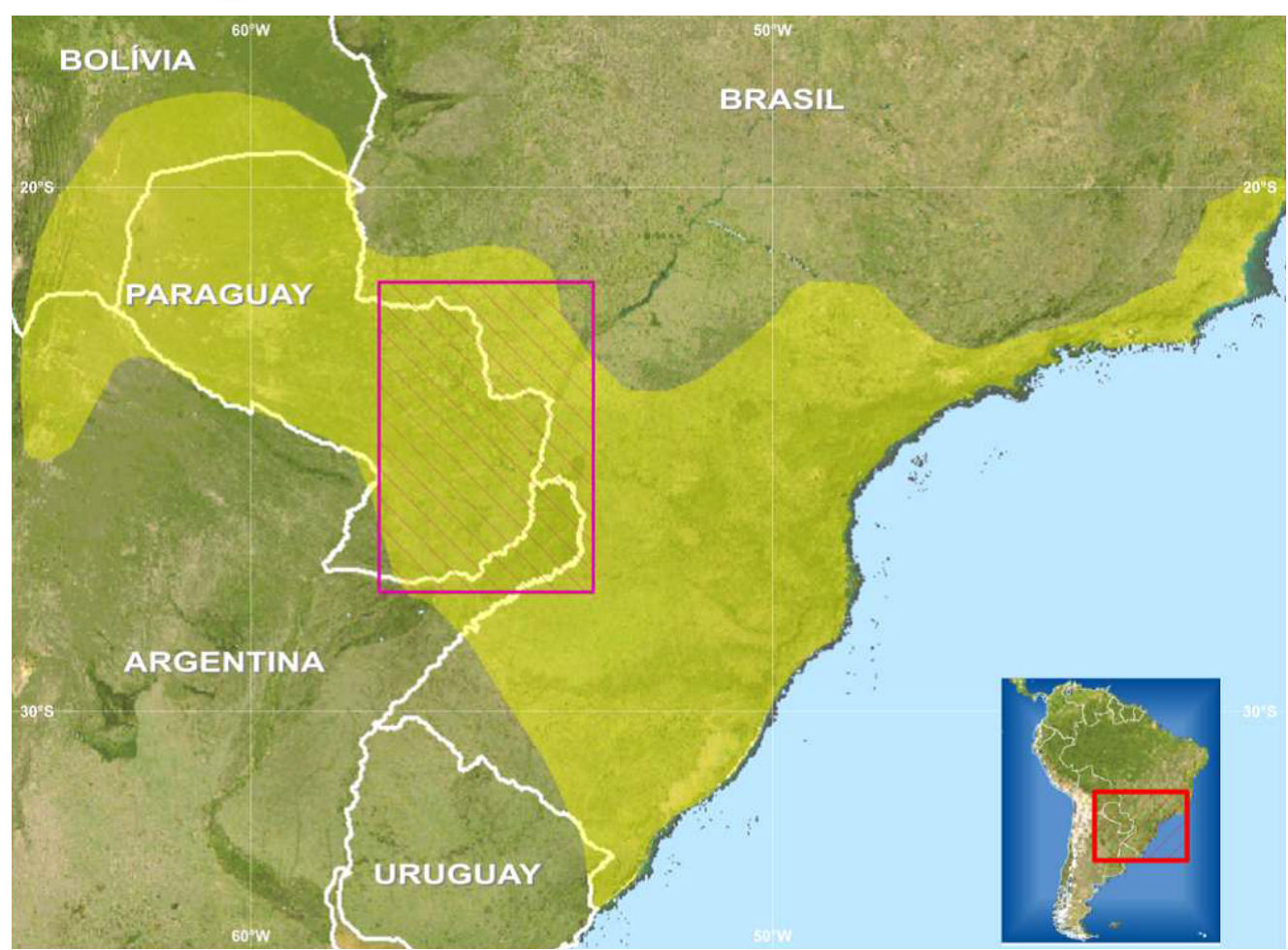

Figura 2. Mapa com território original Guarani e em destaque a localização atual do grupo. Fonte: Azevedo, Brand, Heck, Pereira, \& Melià, 2008.

Nos documentos Jesuíticos, especialmente na obra de Montoya de 1639, podemos extrair diversos relatos que descrevem fundamentos da cultura guarani. Sobre sua produção agrícola encontramos a seguinte menção: "Es gente muy Labradora... siembran maiz, mandioca y otras muchas raízes y legumbres que ellos tiene muy Buenos, dase todo con grande abundançia". (Jesuíta anônimo, apud Cortesão, 1951, p.166).

A organização territorial guarani sustenta os fundamentos dessa forma de viver, se relacionar e produzir. Está associada a esta economia de reciprocidade, mediante a qual se produz a comunicação para divisão de alimentos, bens e conhecimentos. Uma rede de lugares, marcada pela conexão entre pontos no território, relacionando indivíduos que buscam alianças para formação do ser, que se produz pelo senso de comunidade, pela divisão do trabalho, pela alegria das festas, pelo auxilio e respeito às lideranças, normalmente exercido pelos mais idosos, que repassam os conhecimentos através da tradição oral.

Entender essa lógica de organização, reconhecendo os aspectos dessa cultura, requer antes de tudo uma investigação das fontes documentais e antropológicas, determinando o que Sauer explicava sobre os padrões culturais, formas criadas por uma cultura estável, gerada pela relação com as condições ambientais e pelas técnicas associadas ao território. Nesse objetivo, partimos desta revisão bibliográfica, criando um aporte interpretativo que relaciona informações pouco tratadas com outras amplamente discutidas, buscando um caminho para compreender melhor a estrutura social e o sentido da organização territorial guarani.

\subsection{0 modo de ser guarani}

O universo da cultura Guarani se estrutura a partir de três categorias: "Teýy" que entendemos como a estrutura social do grupo, "Tekohá" que entendemos como a organização espacial do lugar e "Guará" que entendemos como uma organização territorial regional. Com um certo cuidado, também para criar uma melhor interlocução com nossas referências, buscamos aproximar esses conceitos ao que entendemos por família, lugar, região e pátria.

Primeiramente, na base da organização guarani está a "Teýy", que corresponde a organização social do grupo. Essa concepção se aproxima ao nosso conceito de família, que se traduz, de maneira 
simplificada, pela soma de diversas famílias nucleares, de pai, mãe e filhos. Os antropólogos e historiadores traduzem o termo "Teýy" como sendo uma "família extensa".

Segundo Susnik (1979), essa família extensa pode ter de oito a sessenta famílias nucleares, constituindo-se, segundo Melià (1987), como a forma mais tradicional e constante do pensamento e da organização social guarani. Dentro de uma "Teýy" encontramos: o avô, que geralmente é o líder principal, suas esposas, seus filhos, netos e bisnetos, também encontramos o que os jesuítas chamavam de vassalos, guaranis não consanguíneos e mulheres de outras culturas indígenas, contudo todos são incorporados como membros da comunidade, com a mesma divisão de trabalho, pois o trabalho é entendido como prática da vida e não como forma de subsistência ou dominação do outro.

Todos os níveis da organização guarani, social, territorial e política, estão associados a um forte poder de chefia e comando, e isso também se mostra dentro da "Teýy". 0 "pai" da família extensa, geralmente um avô, é o homem de maior prestígio dentro da "Teýy", que pode ser tanto um líder político como religioso, ou ambos (Soares, 1996). "Pai chamã era, e continua sendo, o tamôi, o avô mítico, protótipo e figura de todos e cada um dos fundadores da linhagem" (Meliá, Saul, \& Muraro, 1987, p.92)

Os colonizadores e Jesuítas referiam-se a esta liderança como "Cacique", termo apropriado das Antilhas e usado desde a época da chegada do homem europeu (Soares, 1996). Dentro da cultura Guarani a liderança designava-se como "Tuvichá". Diferente do que ocorria na América central, a liderança guarani é caracterizada pela ausência de hierarquia social, em vestimentas, adornos, templos, cidades, centralização de poder político e religioso. Os fundamentos da sociedade guarani ocorrem pelo senso comunitário, organizado por uma liderança política consanguínea ou afetiva. 0 termo Cacique acabou sendo incorporado a cultura guarani atual, como forma de se relacionar com os vocabulários do homem branco, entretanto é preciso atenção, por que muitos documentos tratam dessas lideranças como Tuvichá.

Sobre as povoações e caciques, Montoya (1639) explica: "Viviam, e hoje vivem os gentis (Guaranis) em povoações muito pequenas, mas não sem governo. Possuem seus caciques, os quais todos reconhecem nobreza herdada de seus antepassados, fundada em que tinham vassalos e governavam os povoados" (Montoya, 1639, p. 36. Tradução nossa ${ }^{3}$ ).

Trata-se, a estrutura social da "Teýy", de uma organização co-dependente, com existência vinculada as condições ambientais e organizacionais do território. A existência da "Teýy" também está associada ao modo de constituir os lugares, a formação do habitat como significado do ser e do existir do povo guarani.

A palavra utilizada para a definição dos lugares guaranis é “Tekoha”, palavra já utilizada desde o contato com os primeiros europeus, que na grafia antiga se escreve "Teko'á" que deriva da palavra "Teko", traduzido ao nosso compreender como "modo de ser" ou próximo ao sentido da palavra "cultura". Muito recorrente entre a sociedade guarani é a frase "Sin Tekohá no hay Teko", expressão utilizada para explicar que sem ao território para a formação desses lugares não existe a possibilidade de manter a organização social e da cultura guarani.

O “Tekohá" (esquematicamente representado na Figura 3) seria então, a configuração do lugar, onde se permite a existência, o modo de ser guarani, um território físico com características e formação determinada pela cultura, "[...] aquellos indios vivian a su usança antigua, em tierras, campos, montes, y em pueblos que cada uno montava cinco, o seis casas" (Montoya, 1630, p.14).

De forma simplificada o "Tekohá" é a delimitação de um espaço territorial onde se pode reproduzir todo o modo

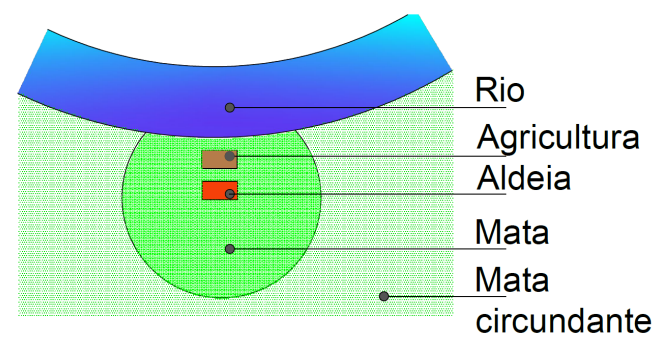

Figura 3. Esquema de um "Tekohá". Fonte: elaboração própria.

\footnotetext{
${ }^{3}$ Texto original: Vivian, y oy viven los Gentiles en poblaciones muy pequeñas, pero no sin govierno. Tenían sus Caciques, en quien todos reconoce nobleza heredada de sus antepassados, fundada em que aviã tenido vassallos, y gouernado pueblo.
} 
de vida guarani; dentro dele está a aldeia, configurada por casas e espaços que atendem a "Teýy"; a área de mata, onde se realiza a caça e a busca por plantas e outros suprimentos; o rio, para a pesca e a comunicação entre os indivíduos de outros "Tekohás"; e a área de agricultura, permanente e temporária, base da alimentação guarani. Assim explica Schaden "Embora o guarani seja incapaz de conceber a vida humana sem as alegrias da caça e da pesca, a base de seu sustento lhe é fornecida pela lavoura" (Schanden, 1974, p.38).

El tekoha es 'el lugar en que vivimos según nuestra costumbre' [...]. Su tamaño puede variar en superficie [...], pero estructura y función se mantienen igual: tienen liderazgo religioso propio (tekoaruvixa) y político (mburuvixa, yvyra'ija) y fuerte cohesión social. Al tekoha corresponden las grandes fiestas religiosas (avatikyry y mitã pepy) y las decisiones a nivel político y formal en las reuniones generales (aty guasu). El tekoha tiene un área bien delimitada generalmente por cerros, arroyos o ríos y es propiedad comunal exclusiva (tekohakuaaha); es decir que no se permite la incorporación o la presencia de extraños. El tekoha es una institución divina (tekoha ñe'e pyru jeguangypy) creada por Ñande Ru (Melià \& Grünberg, 1976, p.218)

Na aldeia, encontrada dentro do "Tekohá", se localiza as casas de residência e os espaços para ritual e festas. São casas grandes, sem divisões, atendendo as necessidades da "Teýy". Nos escritos Jesuíticos de 1620, encontramos a descrição da casa Guarani da seguinte forma:

[...] Habitan en casas bien hechas, no tiene división alguna toda la casa, esta esenta de manera que desde el prinçipio se vee el fin; duermen en unas redes que los españoles llaman hamacas las quales atan en unos palos que quando haçen las casas dejan a proposito y están tan juntas y entretejidas las hamacas de noche que en ninguna manera se puede andar por la casa. Tienen por los lados tapia françesa y cada aposento tiene dos puertas una de cada lado pero no tienen bentanas. no tienen puerta ni caja ni cosa cerrada, todo esta patente y no ay quien toque a cosa de outro (Jesuíta anônimo apud Cortesão, 1951, p.167).

A agricultura é produzida por uma técnica chamada de coivara, não possui localização fixa dentro do Tekohá, a cada 3 anos o local de plantio é mudado para que a terra possa se recuperar e voltar a produzir no futuro. Sobre esta técnica explica outro Jesuíta de 1620:

[...] Sembra en montes y cada tres años por lo menos mudan chácara (lugar), el modo de haçer sus sementeras es: primero arrancón y cortan los arboles pequeños y despues cortan los grandes, y ya cerca de la sementera como están secos los arboles pequenos (aunque los grandes no lo están mucho) les pegan fuego y se abraça todo lo que han cortado, y como es tan grande el fuego quedan quemadas las raizes, la tierra hueca $y$ fertiliçada con la çeniça y al primer aguaçero la siembran de maiz, mandioca y otras muchas raízes y legumbres (Jesuíta anônimo apud Cortesão, 1951, p.166).

A técnica da coivara é muito bem adaptada as condições do território Guarani, a cinzas produzidas pela queima da madeira fertilizam o solo corrigindo sua acidez, o que gera uma grande produtividade para pequenos espaços de plantio, que descansam após produzir de 3 a 5 anos, recuperando a mata queimada para que se repita o processo anos depois.

A técnica é utilizada por diversos outros grupos indígenas na América, mas os guaranis conseguiram adaptá-la aos calendários e as condições locais do território, permitindo que o grupo ocupasse toda a extensão de mata atlântica, se estabelecendo em uma grande área com diferentes características de solo. Essa técnica também é outra causa da organização do grupo em pequenos povoados, já que apesar de muito produtiva não permite o desmatamento de grandes áreas. Segundo Susnik (1983) a área de plantio para alimentar uma "Teýy" corresponde a aproximadamente 1 alqueire, $140 \mathrm{~m}$ por $70 \mathrm{~m}$. Também outro Jesuíta explica:

[...] Sus poblaciones antes de reduçirse son pequenas, porque como siempre en montes quieren estar pocos porque no se les acaben y también por tener sus pescaderos y cagaderos acomodados (Jesuíta anônimo apud Cortesão, 1951, p.167).

(C) Labor \& Engenho, Campinas [SP] Brasil, v.10, n.3, p.249-267, jul./set. 2016. 
Além do "Tekohá", é possível encontrar outra dimensão de organização territorial guarani, que equivale a uma estrutura política regional, também anterior a chegada dos europeus. Segundo Susnik (1964) essa unidade político-regional era chamada de Guará, e afirma que "el hecho de que los primeros contactos de los españoles con los guaraníes basaronse en el trato con los representantes de las unidades sociales, influyó en que las primeras notícias designan tales unidades con nombres de los caciques" (Susnik, 1964, p.3); e de fato podemos verificar a expressão "casa do Guairá", em um dos primeiros mapas do território americano, produzido por Bartomeu Velho em 1562, se referindo a uma região dominada por um cacique Guarani chamado Guairá, na região do alto rio Paraná.

A partir da análise das primeiras legislações coloniais do Paraguai, Susnik (1965) explica que os documentos também apontam para a palavra cacicado, termo que determina o poder político de um cacique sobre uma região. 0 termo Guará corresponde a esta unidade territorial, uma região formada por uma rede de Tekohás, comandada por um cacique principal, interligada territorialmente através dos rios. Essa organização é o que permite a comunicação social dos grupos para festas e distribuição de alimentos e uma rotatividade de pessoas, que mudam de um Tekohá para outro a fim de se casarem ou para se inserirem em outra Teýy. O Guará representa a consciência de uma identidade regional, baseada em ações de união coletiva, tanto para a sobrevivência quanto para a satisfação das necessidades humanas e espirituais.

No livro de Montoya (1639), o autor explica que os grupos Guaranis se encontram periodicamente comunicando os Tekohas, termo que o jesuíta chamava de "Pueblo", especialmente em ocasiões de festas ou para produzir alianças. Montoya conta como os jesuitas chegavam até os "tekohas", tentando convencer os grupos para formarem as Reduções Jesuíticas:

[...] Salimos el Padre Joseph, y yo, por aquellos rios a combidar a los Indios a que se reduxessen en poblaciones grandes [...] Llegamos a un pueblo, cuyo Gouernador era un gran cacique, gran Mago y familiar amigo del demonio [...] Llegamos a otro pueblo, que governava un honrado Cacique, desejoso de oír las cosas de su salvacion, [...] pero habia un gran Ministro suyo, que andava en mission: de pueblo en pueblo, engañando aquella pobre gente, predicandose que el era Diós, y hombre que el daña las lluvias, y las quitava (Montoya, 1639, p.36. Grifo nosso).

No texto Montoya expõem claramente essas comunicações e reafirma a ação de comando dos Caciques em unidades territoriais regionais.

Especificamente sobre a forma de circular no território, Montoya escreve o seguinte: "Se iva de um lugar a outro por rios, que los ay muy grándes, y en ellos parages el rio Paraná, que es el que comunmente llaman de la Plata, tiene por algunas partes a dos leguas de ancho". Também conta um episódio em que andava por terra no território sendo alertado por Guaranis para que se locomovesse apenas pelos rios:

[...] encontre unos indios [guaranis], e me dieron aviso de uma embarcación que estava em um Arroyo, aconsejandome no caminhasse por tierra: porque sin duda, me matarian los indios bárbaros que habitan por aquellos montes (Montoya, 1639, p.48).

Montoya também nos dá a definição do que seria o termo Redução, afirmando que o nome provém da ação de reduzir os pequenos povoado a um povoado grande, criando com essa união as chamadas Reduções Jesuíticas, [...]

[...] Llamamos reduciones pueblos de indios que vivendo a su antigua usança em montes, serras e vales, e escondidos arroyos, em três, quatro e seis casas solas, separadas a légua, dos, tres y mas, unos de otros, los reduxo a la diligencias de los Padres, a poblaciones grandes, y a vida política e humana (Montoya, 1630, p.23).

Através das descrições de Montoya podemos chegar a esquemas gráficos para a representação do Guará, formado por "Tekohas", distantes um dos outros de cinco até quinze quilômetros ou mais, interligados pelos grandes rios da Bacia do Prata em meio a densa mata atlântica. 

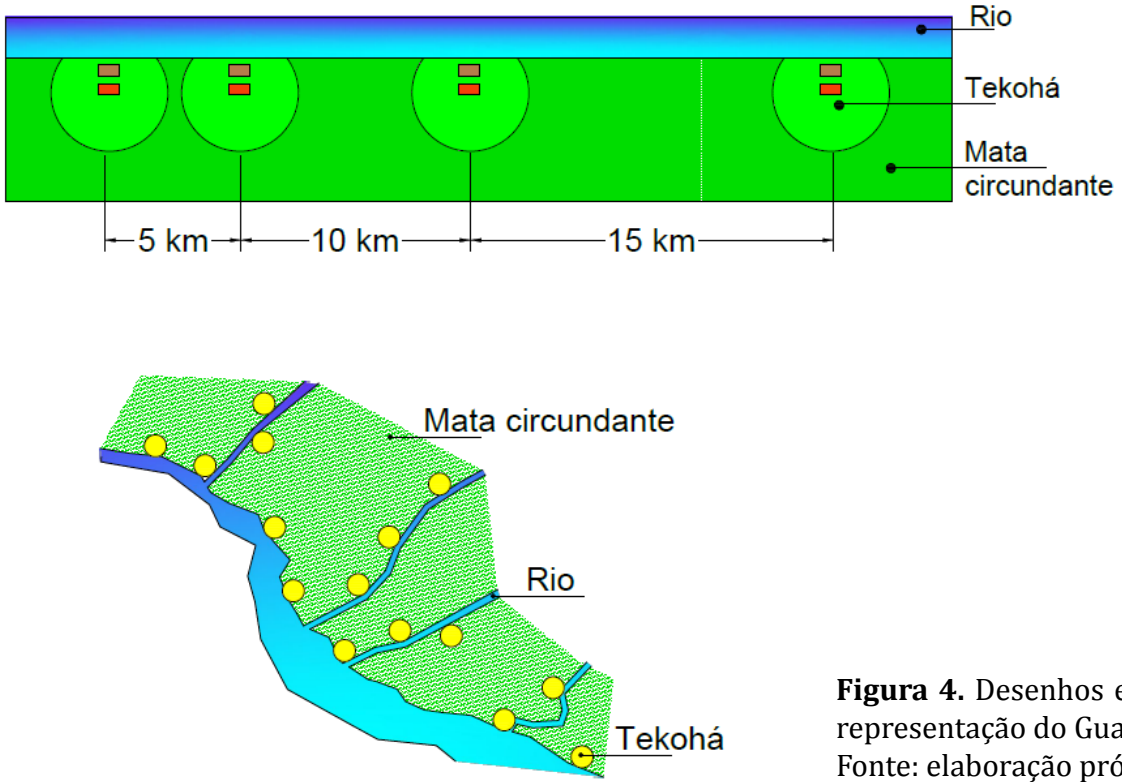

Figura 4. Desenhos esquemáticos da representação do Guará: Fonte: elaboração própria.

\section{A inserção de modelos urbanos como meio civilizatório: aldeamentos coloniais e imperiais}

Separemos em primeiro lugar a quem pode dar-se o nome de cidadão de uma cidade $e$ quem realmente é um cidadão... somente é cidadão o indivíduo dotado de um certo poder, e basta gozar desse poder para ser um cidadão (Aristóteles).

As definições de Aristóteles correspondem a um conceito político de cidade, sendo cidadão aqueles que podem intervir de forma deliberativa e judicial na cidade, aqueles que possuem $o$ poder de comandar e decidir os rumos da cidade.

As tentativas de criar cidades espanholas e os objetivos Jesuítas de conversão espiritual criaram as primeiras atuações europeias para transformar o Guarani em habitantes de grandes cidades. Nas primeiras legislações de ordenação do território, os espanhóis já buscavam um controle da mobilidade Guarani com o seu empadronamento - política de contagem da população e fixação definitiva nos lugares - meio entendido como o mais efetivo para a hispanização do grupo. Nas legislações paraguaias, produzidas pelo Governador Irala em 1556, observamos a preocupação de controlar a população para que não se comunicassem entre os "Tekohás" [...]

[...] no se muden vayan ni ausenten de sus casas y pueblos a otros pueblos y casas ni parte alguna e allí vivan permanezcan todo el tiempo que Dios les diere de vida [...] (Paraguai, 1556, p.511).

Assim, mesmo antes da implantação das Reduções Espanholas no Guairá, que só tomaram força por volta de 1600, as legislações paraguaias buscavam essa junção dos Tekohás, sendo uma medida de organização do trabalho e implantação do sistema de encomiendas espanholas ${ }^{4}$. A formação destas aglomerações não se fixava na formação da cidadania, muito menos em manter a organização da "teýy" como unidade sócio econômica e cooperativa, possuía o único objetivo de organizar um sistema mais produtivo para escravidão e controle da mão de obra guarani. Explicando como os guaranis eram tratados nestas primeiras cidades espanholas escreve um Jesuítas em 1620: [...]

[...] Nunca los españoles ios han puesto en poliçia ni enseñado officio aunque son capaçes del los que ha ávido texedores, Herreros, carpinteros y de otros offiçios los tenían los españoles, cuyos eran, en sus casas y goçaban de todo su trabajo como se fueran esclavos y asi casi no ay indios que sepan officios ni que se aprovechen de los que saben (Jesuíta anônimo apud Cortesão 1951, p.168).

\footnotetext{
${ }^{4}$ Sistema de encomiendas espanholas: Instituição Jurídica imposta pela coroa com vistas a regular o recolhimento de tributos e exploração do trabalho indígena por um encomendeiro.
} 
Por estes contextos de escravidão nas cidades espanholas, os Jesuítas conseguiram espaço para difundir a fé cristã em troca de proteção aos guaranis, impondo também a junção dos "Tekohás" em modelos urbanos que chamavam de Reduções. Da mesma forma que na cidade espanhola o sistema de Redução também desorganizava a "Teýy", pois para criar a concepção da família católica, adotava casas unifamiliares, abrigando apenas o pai, mãe e filhos.

As Reduções mantinham um sistema cooperativo entre elas, isolando o guarani do comércio espanhol e português, mantendo também a figura do cacique como aparente líder político. As pregações dos jesuítas se desenvolveram no território do Paraná no final do século XVI, e estima-se que mais de cem mil guaranis foram reduzidos pelos jesuítas. A destruição destas reduções ocorre a partir de 1628, quando os bandeirantes paulistas atacam o território em busca de escravos, motivando parte da população a se deslocar até as reduções do Tape, onde se juntaram para formar os Sete povos das missões Jesuíticas.

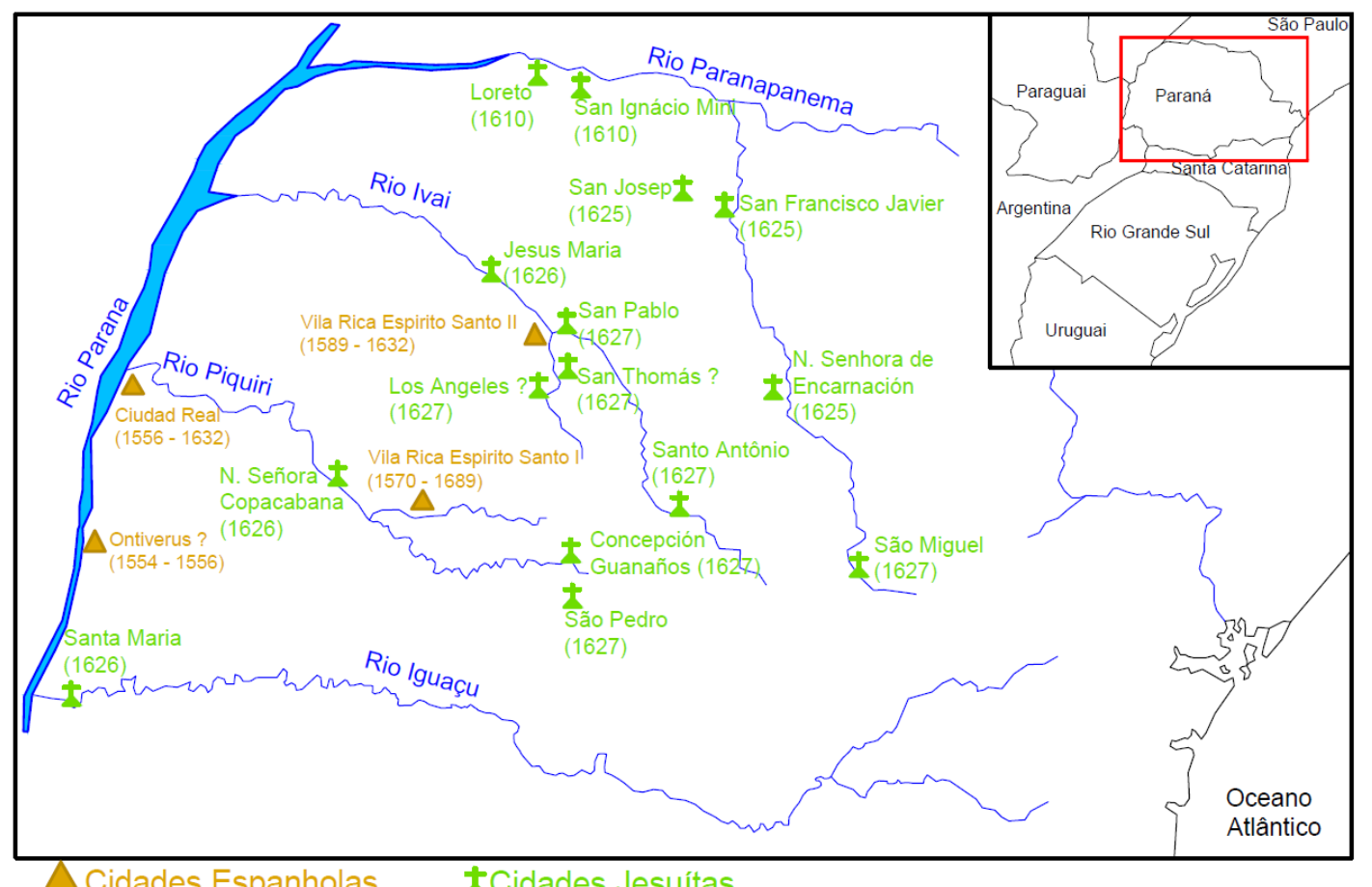

Figura 5. Localização das cidades e reduções espanholas no atual estado do Paraná a partir de 1600 Fonte: Elaboração própria a partir de dados do Museu Arqueologia do Paraná.

Devido ao tratado de Madri, em 1750, temos uma separação histórica do povo guarani. Isto é, a partir deste momento passa efetivamente a existir um guarani espanhol e um guarani Português, ambos submetidos a políticas territoriais diferentes, que traçam processos de aculturação diferenciados, onde cada grupo se relacionar com diferentes ideias e formas de se organizar.

Fundamentalmente as legislações portuguesas caminham no mesmo sentido das legislações espanholas, buscam estabelecer uma política de controle e organização territorial. A partir de 1758 a coroa portuguesa criar uma nova legislação que dá início a um sistema nacional de aldeamentos, que teve algumas mudanças conceituais ao longo dos séculos, mas que efetivamente perdura até a entrada do século XX.

É importante frisar a distinção entre os termos "aldeia" e "aldeamento". 0 termo aldeamento deve ser entendido como os núcleos indígenas criados a partir de uma ação efetiva do estado, com planos e projetos de urbanização, enquanto o termo aldeia se vincula aos núcleos indígenas formados de forma espontânea, ou ainda aqueles produzidos pelas ordens religiosas.

Em um primeiro momento, o objetivo dos aldeamentos era a formação de vilas para a defesa do território, para isso apostava em modelos urbanos que pudessem conduzir a esperada civilidade 
indígena, formando cidadãos dignos de habitar as futuras cidades. Estes planos se traduziam na assimilação dos grupos indígenas e sua transformação em trabalhadores produtivos, determinando como deveriam se organizar, produzir e viver, atendendo as necessidades da Coroa Portuguesa.

Essa Legislação se inicia com o seguinte texto: [...]

[...] Sendo evidente, que as paternais providências de Nosso Augusto Soberano, se dirigem unicamente a cristianizar, e civilizar estes até agora infelizes, e miseráveis Povos, para que saindo da ignorância, e rusticidade, a que se acham reduzidos, possam ser úteis a si, aos moradores, e ao Estado (Brasil, 1755).

Essa legislação recebe o nome de "Alvará do diretório dos índios", primeiramente aplicada nos estados do Pará e Maranhão, onde o território necessitava de maior defesa contra invasores, e posteriormente, em 1758, aplicada em todo o território. A política se pautava em oferecer a liberdade indígena, tirá-los da administração das ordens religiosas e transformá-los em habitantes de cidades civis [...]

[...] Estabeleci inviolavelmente a liberdade das pessoas, bens, assim de raiz, como semoventes e móveis a favor dos índios [...] e o independente exercício da agricultura [...] e do comércio [...] dando a eles uma fórma de governo própria para civilizallos e attrahillos a este único e adequado meio ao Grêmio da Santa e Madre Igreja (Brasil, 1758).

A lei cria um agente do estado chamado de diretor, e se traduz em um apanhado de orientações para criar vilas com populações indígenas, que seriam oficialmente constituídas para criar um novo sistema de comercio, conduzindo e organizando a vida dos grupos indígenas, em benefício do Estado e do homem branco.

[...] Haverá em cada uma das sobreditas Povoações, enquanto os Índios não tiverem capacidade para se governarem, um Diretor, o qual deve ser dotado de bons costumes, zelo, prudência, verdade, ciência da língua, e de todos os mais requisitos necessários para poder dirigir com acerto os referidos índios debaixo das ordens e determinações (Brasil, 1755).

$[\cdots]$

[...] Não se podendo negar, que os índios se conservaram até agora na mesma barbaridade, como se vivessem nos incultos sertões em que nasceram, praticando os péssimos, $e$ abomináveis costumes do Paganismo, não só privados do verdadeiro conhecimento dos adoráveis mistérios da nossa Sagrada Religião, mas até das mesmas conveniências Temporais, que só se podem conseguir pelos meios da civilidade, da Cultura, e do Comércio (Brasil, 1755).

Muitos destes projetos possuem as características dos projetos pombalinos, seu traçado é ortogonal, gerado a partir da praça do comércio, onde se localiza a casa do diretor e os edifícios principais, existe também uma preocupação com a regularidade e dimensão das fachadas, produzidas normalmente com 11 metros, valor equivalente ao dobro do tamanho do lote tradicional português. Outros projetos, também do diretório dos índios, foram adaptados ou totalmente refeitos a partir dos modelos das ordens religiosas, gerando uma linguagem que nos remete aos traçados das Reduções Jesuíticas.

A lei do diretório dos índios determina que o Diretor seja um homem branco, disposto a atender os ditames da nova política, persuadindo a população a formar povoados e vilas. A norma estabelece diversos procedimentos para a formação dos aldeamentos, iniciando-se pela organização política e institucional: [...]

[...] Que os Índios existentes nas Aldeias, que passarem a ser Vilas, sejam governados no Temporal pelos Juizes Ordinários, Vereadores, e mais Oficiais de Justiça (Brasil, 1755).

(C) Labor \& Engenho, Campinas [SP] Brasil, v.10, n.3, p.249-267, jul./set. 2016. 


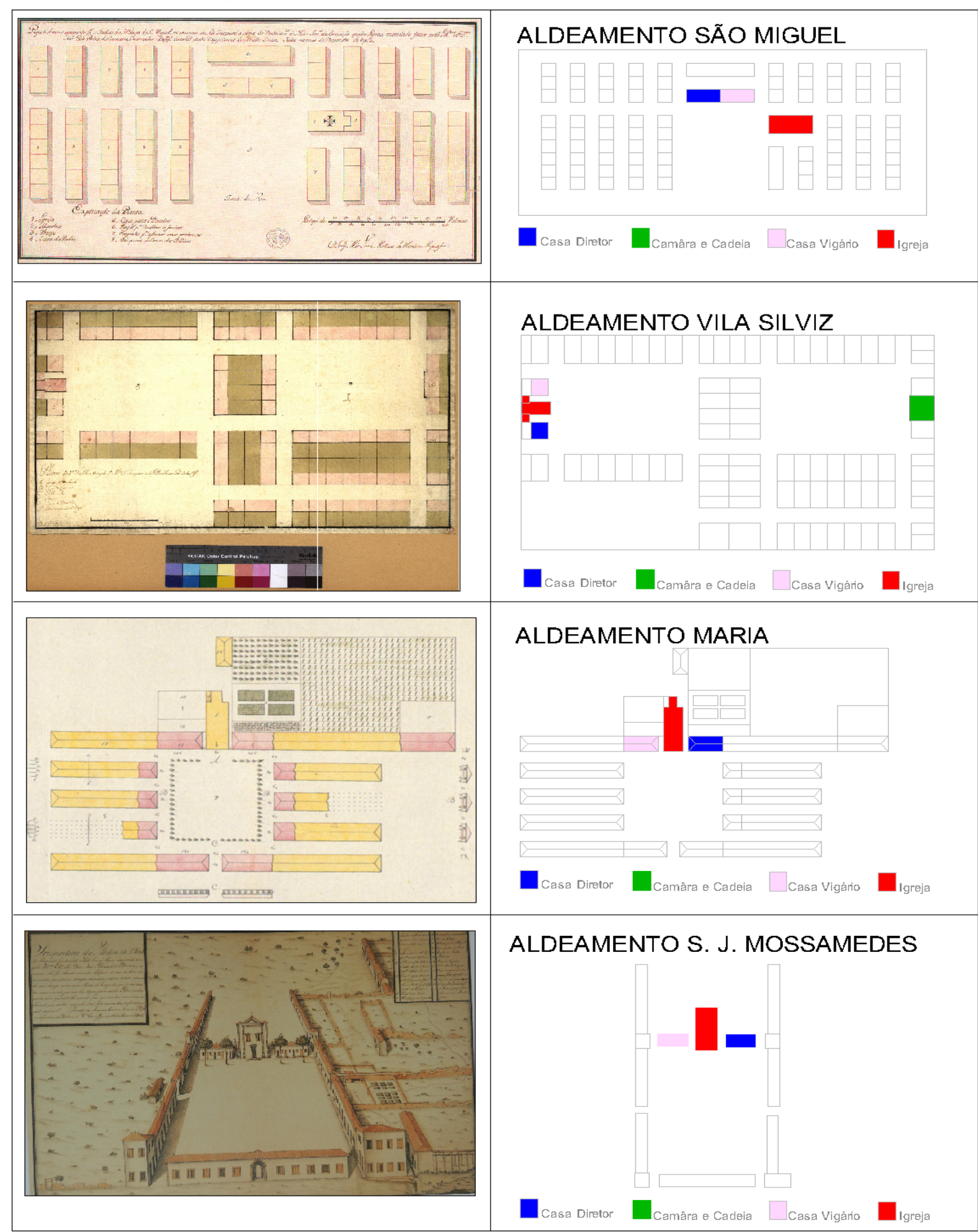

Figura 6. Aldeamentos coloniais.

A lei determina que os diretores orientem os indígenas na construção dos edifícios públicos, para que sejam seguros e possuam a grandeza esperada para representar a importância das instituições: [...]

[...] que nelas se estabeleçam casas de Câmera, e Cadeias públicas, cuidando muito em que estas sejam erigidas com toda a segurança, e aquelas com a possível grandeza (Brasil, 1755).

Instituições como a escola são amplamente tratadas na legislação, onde se estabelece o número mínimo de edifícios, a separação entre meninos e meninas, as regras para se eleger professores brancos, a educação no idioma português, as atividades que devem ser oferecidas para as crianças. 
[...] Haverá em todas as Povoações duas Escolas públicas, uma para os Meninos, na qual se lhes ensine a Doutrina Cristã, a ler, escrever, e contar na forma, que se pratica em todas as Escolas das Nações civilizadas; e outra para as Meninas, na qual, além de serem instruídas na Doutrina Cristã, se lhes ensinará a ler, escrever, fiar, fazer renda, costura, $e$ todos os mais ministérios próprios daquele sexo (Brasil, 1755).

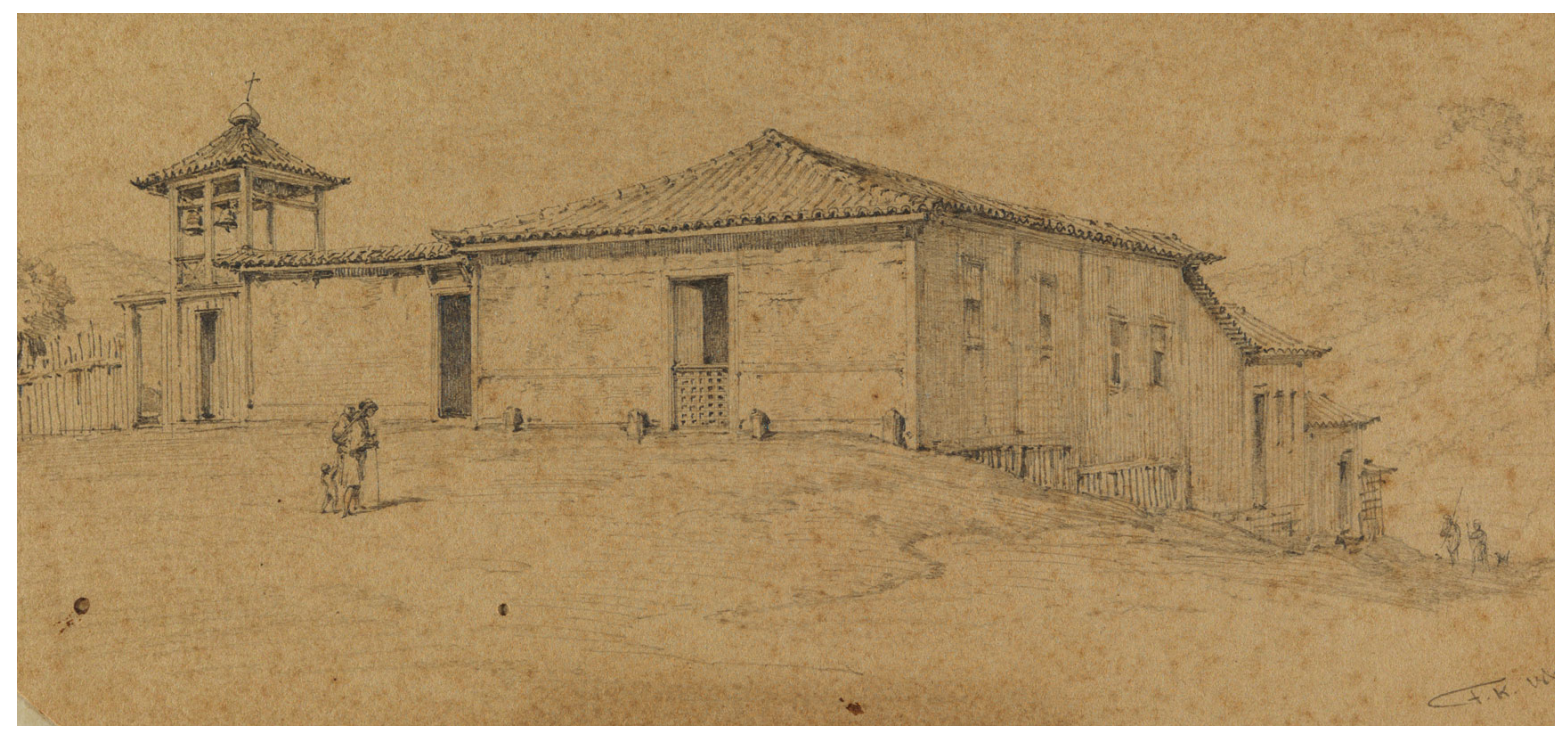

Figura 7. Casa do diretor, aldeamento de São Pedro de Alcântara. Fonte: Desenho Keller Franz, 1867. Biblioteca Nacional do Rio de Janeiro.

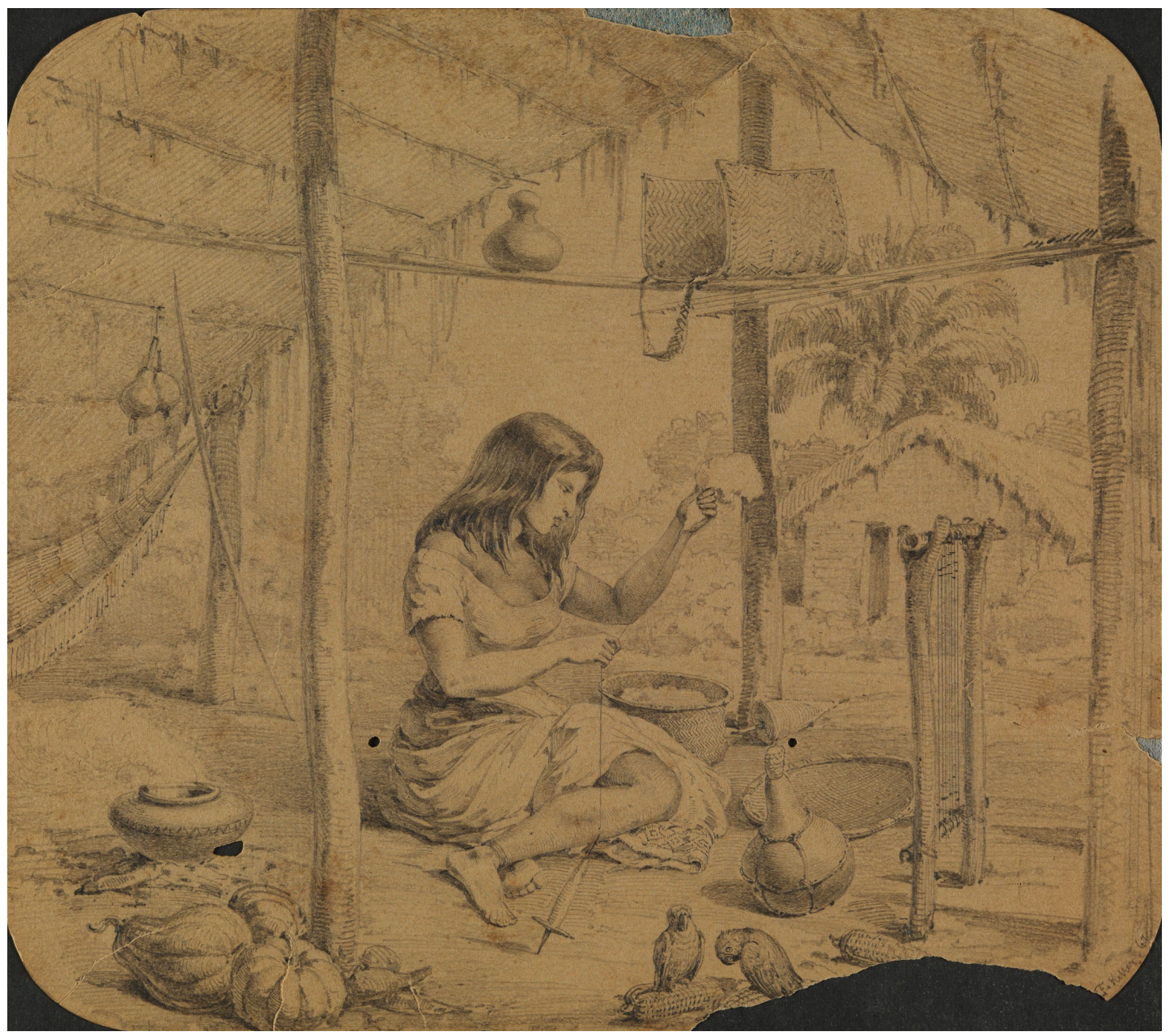

Figura 8. Índia fiando algodão, Aldeamento Guarani, rio Paranapanema 1860. Fonte: Desenho Keller F., Biblioteca Nacional do Rio de Janeiro. 
Outro ponto importante é a forma como se devem construir as habitações. A arquitetura tradicional indígena, desde a forma de construir, habitar, uso de materiais e técnicas, é apontada como uma das causas da incivilidade. A norma determina que os diretores observem rigorosamente as técnicas da arquitetura dos homens brancos, respeitando a sua forma e seu desenho, bem como o uso e o tratamento dos materiais, para que as urbanizações sejam constituídas e destacadas pela nobreza de seus edifícios:

[...] Sendo também indubitável, que para a incivilidade, e abatimento dos Índios, tem concorrido muito a indecência, com que se tratam em suas casas [...] na qual vivem como brutos; Cuidarão muito os Diretores em desterrar das Povoações este prejudicialíssimo abuso, persuadindo aos Índios que fabriquem as suas casas a imitação dos Brancos: fazendo nelas diversos repartimentos, onde as Famílias possam guardar, como Racionais, as Leis da honestidade, e polícia (Brasil, 1755. Grifo nosso).

$[\ldots]$

[...] Empregarão os Diretores um particular cuidado em persuadir aos Índios, que façam casas decentes para os seus domicílios, desterrando o abuso, e a vileza de viver em choupanas a imitação dos que habitam como bárbaros o inculto centro dos Sertões, sendo evidentemente certo, que para o aumento das Povoações, concorre muito a nobreza dos Edifícios (Brasil, 1755. Grifo nosso).

As povoações deveriam se iniciar com no mínimo 150 moradores, sendo também função dos diretores encontrar meios para unir as pequenas aldeias, criando povoações maiores, para que pudessem exercer a vida civil e a prática do comércio.

[...] Que as Povoações dos Índios constem ao menos de 150 Moradores, por não ser conveniente ao bem Espiritual, e Temporal dos mesmos Índios, que vivam em Povoações pequenas, sendo indisputável que à proporção do número de habitantes se introduz nelas a civilidade e o Comércio (Brasil, 1755).

Observa-se que por mais de 150 anos, entre o período de 1750 e 1900, a política aplicada para a população indígena se resumiu ao confinamento nestas povoações, onde deveriam se adaptar a vida social e religiosa do homem branco.

As terras da lavoura indígena deveriam ser demarcadas nas proximidades de suas vilas, em áreas adjacentes, áreas suficientes para o sustento e comércio das populações indígenas.

[...] cuidarão logo [os diretores] em examinar com possível exatidão, se as terras, que possuem os ditos Índios (que na forma das Reais ordens de Sua Majestade devem ser adjacentes às suas respectivas Povoações) são competentes para o sustento das suas casas, e famílias; e para nelas fazerem as plantações, e as lavouras; de sorte, que com a abundância dos gêneros possam adquirir as conveniências, de que até agora viviam privados, por meio do comércio em benefício comum do Estado (Brasil, 1755).

É importante lembrar que muitos aldeamentos são produzidos em áreas próximas as vilas portuguesas, servindo como produtor de mão de obra, e também para manutenção de alimentos para as cidades e as tropas do governo.

Era obrigação dos diretores controlar e prestar conta do trabalho indígena, informando ao Estado aqueles que se recusavam a trabalhar, para que fossem devidamente castigados. A citação abaixo fala da obrigação dos povoados indígenas em oferecer gêneros alimentícios para as cidades do Estado do Pará e Maranhão: [...]

[...] Serão obrigados os Índios a plantar feijão, milho, arroz, e todos os mais gêneros comestiveis,...com os quais se utilizarão os mesmos Índios; se aumentarão as Povoações; e se fará abundante o Estado [...] Terão os Diretores um especial cuidado em que todos os Índios, sem exceção alguma, façam Roças de maniba [mandioca], não só as que forem suficientes para a sustentação de suas casas, e famílias, mas com que se possa prover abundantemente o Arraial do Rio Negro; socorrer os moradores desta Cidade; e municionar as Tropas, de que se guarnece o Estado (Brasil, 1755). 
[...] Serão obrigados os Diretores a remeter todos os anos uma lista das Roças [...] declarando nela os gêneros, que se plantaram [...] e também os nomes assim dos Lavradores, que cultivaram os ditos gêneros, como dos que não trabalharam [...] para que possa o mesmo Governador louvar em uns o trabalho, e a aplicação; e castigar em outros a ociosidade, e a negligência (Brasil, 1755).

Desconsiderar conhecimentos, técnicas e formas tradicionais de ocupar e viver no território, concentrando e aglomerando essas populações indígenas, soluciona diversos entraves na questão fundiária brasileira. No período imperial a formação dos aldeamentos tinha a finalidade de deixar a terra livre para a implantação da política da lei de terras, funcionando também como um ponto de apoio para os colonos que adquirem terras no interior do Brasil.
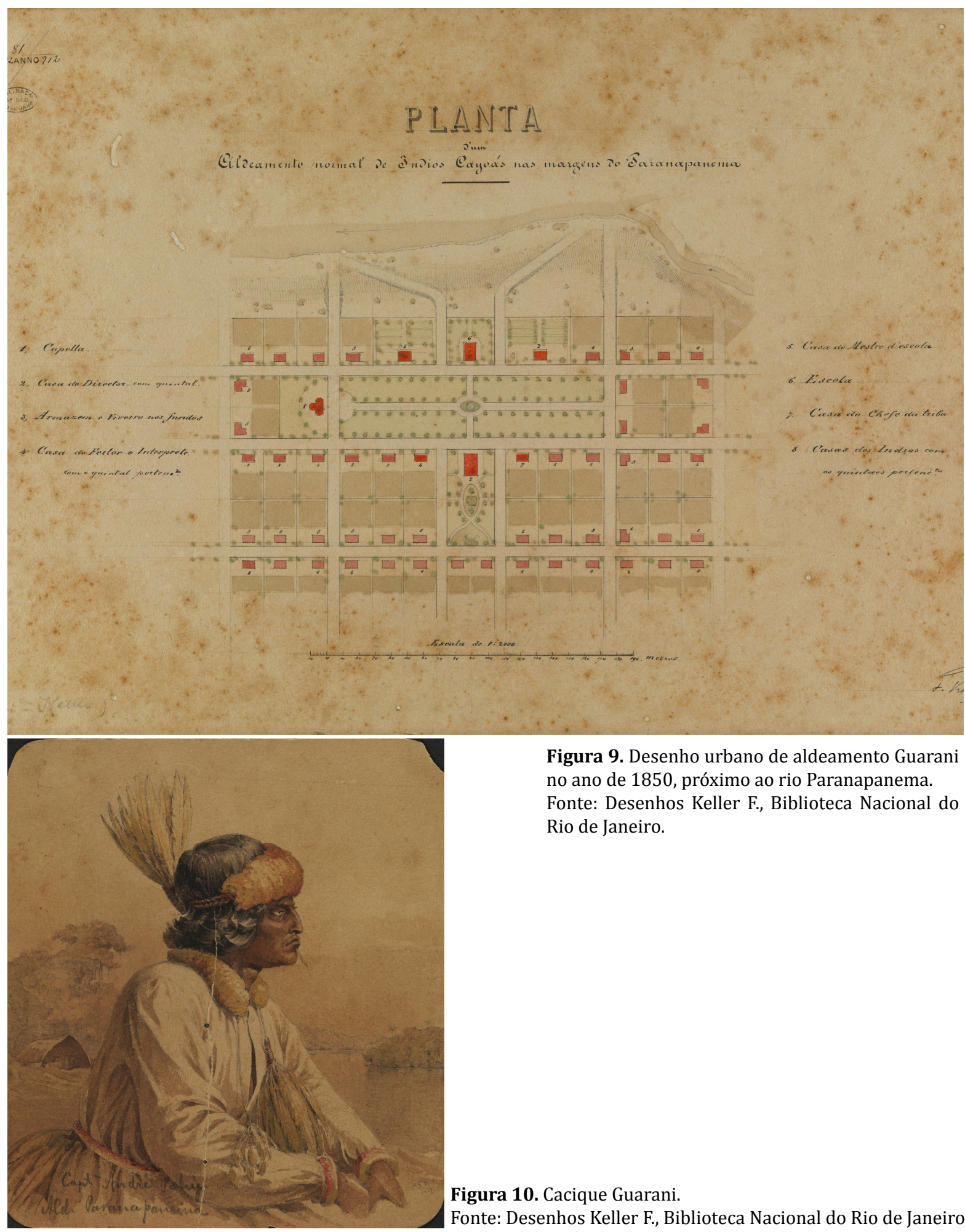

Figura 9. Desenho urbano de aldeamento Guarani no ano de 1850, próximo ao rio Paranapanema. Fonte: Desenhos Keller F., Biblioteca Nacional do Rio de Janeiro.

Figura 10. Cacique Guarani.

Fonte: Desenhos Keller F., Biblioteca Nacional do Rio de Janeiro. 


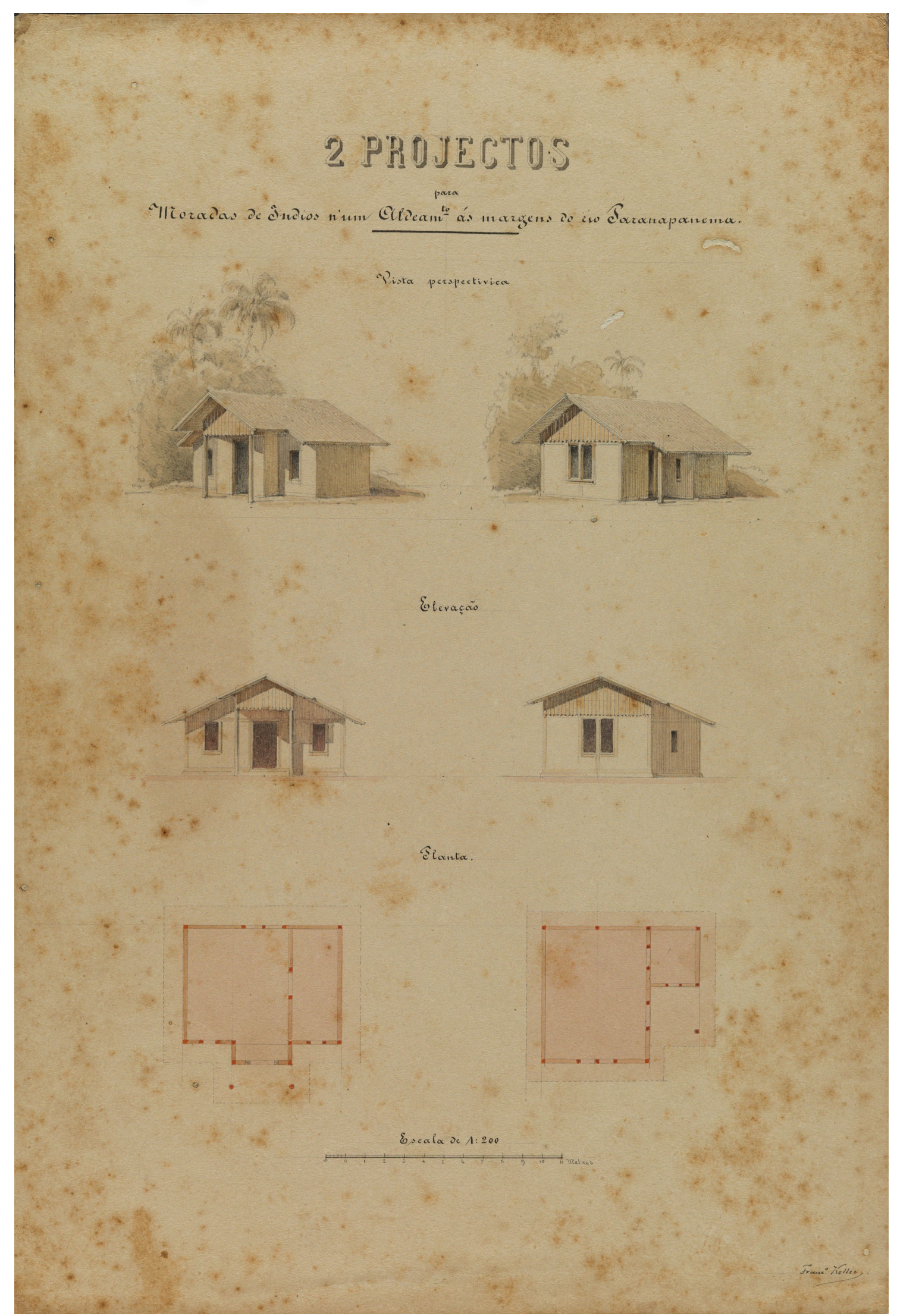

Figura 11. Desenho das casas de aldeamento Guarani no ano de 1850, próximo ao rio Paranapanema. Fonte: Desenhos Keller F., Biblioteca Nacional do Rio de Janeiro. 


\section{Conclusão}

Os processos de aculturação, que sucessivamente marcam a história da cultura guarani, constituem dramáticos episódios de injustiça, morte e violência. Ao longo da história diversos modelos urbanos são impostos a população guarani como meio de conversão e civilização. Estes modelos nunca tiveram o objetivo de formar cidadãos livres e de direitos, bem como não respeitaram nenhum padrão cultural de relação com o território. 0 objetivo desta política era a formação de cidades e defesa do território, depois tornou-se um meio de liberar as terras para colonização e impor o trabalho agrícola para gerar excedentes e sustentar outros núcleos urbanos portugueses, mas teve como dramática consequência a desestruturação da cultura territorial guarani, largamente construída e que conseguia um delicado equilíbrio com o território.

Não obstante às políticas atuais de proteção a vida indígena, que se faz como primeira meta em defesa de uma população ameaçada, é necessário um avanço nas reflexões de como podemos atuar para garantir não apenas a vida, mas a dignidade de um grupo que a séculos busca um reconhecimento e uma valorização de seu modo de vida e de suas tradições.

Antes de tudo, se faz necessário um estudo e uma abordagem técnica dessa cultura, enquanto bem e patrimônio da cultura brasileira, reconhecendo a existência de uma organização territorial, que está associada à sua relação com o território, motivadora de suas crenças, suas tradições e sua organização social, atuando como um suporte ao meio de vida e ao modo de ser guarani.

As relações territoriais indígenas podem ser observadas através do conceito de paisagem cultural, utilizado atualmente como instrumento de defesa do patrimônio. 0 conceito de Paisagem Cultural nos orienta na percepção, valoração e reconhecimento de culturas como a guarani, desenvolvidas e geradas a partir das relações com o território.

0 respeito devido a cultura guarani nos obriga a conhecer mais sobre seu modelo de organização, desde a escolha do território, tipo de implantação, forma de habitar, viver e se comunicar. Tentando a partir disso, compreender como estes padrões se relacionam com componentes sociais de sua cultura, encontrando mecanismos que possam preservar suas memórias, pois, quem perde suas memórias perde também sua identidade.

\section{Referências}

Aristóteles (2006). Política, Livro III. São Paulo: Martin Claret.

Azevedo, M., Brand, A., Heck E., Marques L., \& Melià. B. (2008). Caderno Guarani Retã. <http:// pib.socioambiental.org> (consulta: 10/08/2015).

Brasil (1755). Alvará de 7 de junho de 1755. Diretório dos Índios. Pará e Maranhão.

Brasil (1758). Alvará de 8 de maio de 1758. Estende o Diretório dos Índios a todo o Brasil.

Brasil (1845). Decreto $n^{\circ}$ 426, de 24 de Julho de 1845. Regulamento das Missões de catequese e civilização dos indígenas do Brasil.

Breda, T. (2014). Guaranis resistem a preconceito enquanto exigem demarcações no Paraná. Disponível em <http://www.redebrasilatual.com.br>. (consulta: 08/07/2015).

Cortesão J. (1951). Jesuítas e Bandeirantes no Guairá (1549-1640) Manuscritos da Coleção de Angelis. Rio de Janeiro: Biblioteca Nacional do Brasil.

Melià, B., \& Grünberg (1976). Los Paî-Tavyterã: Etnografia guarani del Paraguai contemporaneo, in: Suplemento Antropológico de la Revista del Ateneo Paraguayo, Vol XI no 1-2.

Meliá, B., Saul, J., \& Muraro, V. (1987). O Guarani, uma Bibliografia Etnológica. Santo Angelo: Fundação PróMemória. FUNDAMES. 
Nimuendajú, C. (1910a). Nimongaraí. Mana 7, pp.143-149, 2001.

Nimuendajú C. (1910b). Apontamentos sobre os Guarani. Revista Tellus 24, pp.311-360, 2001.

Sauer, C. (1925) The Morphology of Landscape. Geography. University of California Publications 2, pp.19-54.

Schaden, E. (1974). Aspectos fundamentais da cultura Guarani. São Paulo, Editora Edusp.

Susnik, B. (1964). El Guaraní en la vida Socio-Económica Colonial. Revista de Sociología 01, pp.30-48.

Susnik, B. (1965). El Guaraní Colonial. "El indio Colonial del Paraguay". Asunción: Museo Etnográfico Andrés Barbero.

Susnik, B. (1983). "Los Aborígenes de Paraguay", Tomo V. Ciclo Vital y Estructura Social. Asunción: Museo Etnográfico Andrés Barbero.

Paraguai (1556). Ordenanzas de Irala sobre repartimientos y encomiendas. 